\title{
Neu-Laxova Syndrome: An Unusual Association with Kyphosis
}

\author{
Amandeep KAUR ${ }^{1}$, Vijayalaxmi SURANAGI ${ }^{1}$, Kamal PATIL ${ }^{2}$, Hema BANNUR ${ }^{1}$
}

Department of ${ }^{1}$ Pathology and ${ }^{2}$ Obstetrics and Gynaecology, KLE University, Belgaum, KARNATAKA, INDIA

\begin{abstract}
The Neu-Laxova syndrome is a rare autosomal recessive condition associated with neuro-ectodermal abnormalities and other patterns of severe malformations leading to prenatal or early postnatal lethality. Association with kyphosis is an extremely rare finding. A fetus born from a 25-year-old gravida at 30 weeks gestation was diagnosed with Dandy Walker syndrome with severe intrauterine growth restriction on ultrasonography. On post-mortem examination after termination of pregnancy, the fetus showed facial dysmorphology with microcephaly, smooth shiny skin and kyphosis. Skin histology showed hyperkeratosis, edema and increased subcutaneous fat suggestive of ichthyosis. On the basis of gross and microscopic features seen, a diagnosis of Neu-Laxova syndrome was made.
\end{abstract}

Key Words: Neu-Laxova syndrome, Lissencephaly, Kyphosis, PHGDH mutation

\section{INTRODUCTION}

The Neu-Laxova syndrome (NLS) is a rare disorder with only 70 cases of this syndrome reported so far (1). NLS was first reported by Richard Neu in 1971 and Renata Laxova in 1972. It is a lethal, autosomal recessive condition associated with complex neuro-ectodermal abnormalities and other different patterns of severe malformations. The majority of the babies are either stillborn or die in the early neonatal period (2). Typical features of this syndrome include skin changes, limb abnormalities, excessive subcutaneous edema, brain malformations and an unusual association with kyphosis.

\section{CASE REPORT}

A 25 -year-old gravida 3 para 2 living 2 woman with 30 weeks period of gestation was referred for antenatal examination. The fetus showed abnormal facial features and thickened skin and was diagnosed with the Dandy-Walker syndrome with severe intrauterine growth restriction (IUGR) on ultrasonography. On post-mortem examination after termination of pregnancy, the fetus weighed 375 grams, with the length and head circumference of $27 \mathrm{~cm}$ and 18.5 $\mathrm{cm}$ respectively. All body measurements were appropriate for 19-20 weeks of gestation. X-ray showed microcephaly, kyphosis and enlarged orbital ridges (Figure 1). The autopsy findings of the fetus showed microcephaly, mild proptosis, hypertelorism, flattened nose, thickened ears, lips, micrognathia and kyphosis. The skin was taut, shiny

(Turk Patoloji Derg 2018, 34:259-261)

Received : 17.12.2015 Accepted : 09.03.2016 and thickened diffusely. Flexion contractures were seen in the upper and lower limb. Placenta was not received.

On internal examination, the brain weighed only 15 grams and showed flattened sulci and gyri suggestive of lissencephaly. The brain also showed dilated lateral ventricles, absence of corpus callosum, markedly hypoplastic cerebellum and brain stem (Figure 2). However, dilatation of the third ventricle was not seen. Cerebellar vermis agenesis was not associated with fourth ventricle cyst.

The thoracic and abdominal organs were normally oriented. Microscopic sections from the skin showed hyperkeratosis, edema and increased subcutaneous fat suggestive of ichthyosis (Figure 3). Section from brain cortex showed loss of neurons. Since facilities for cytogenetic studies are not available at our institution, chromosomal status of the fetus could not be ascertained.

\section{DISCUSSION}

NLS is a rare genetic disorder that is inherited as an autosomal recessive trait. Karyotype results are normal. Rocio Acuna-Hidalgo et al. identified homozygous mutations in PHGDH, a gene involved in the first and limiting step in L-serine biosynthesis, as the cause of the disease (3). Scott et al. reported 13 cases and summarized the components of this syndrome as abnormalities of placentation, severe IUGR, edema, ectodermal dysplasia, and the severe CNS developmental defect (4). Severe IUGR is noted in $100 \%$ of the cases. The abnormalities of

Correspondence: Amandeep KAUR

Department of Pathology, KLE University, Belgaum, KARNATAKA, INDIA E-mail: amanprince88@gmail.com Phone: +91974375 4924 


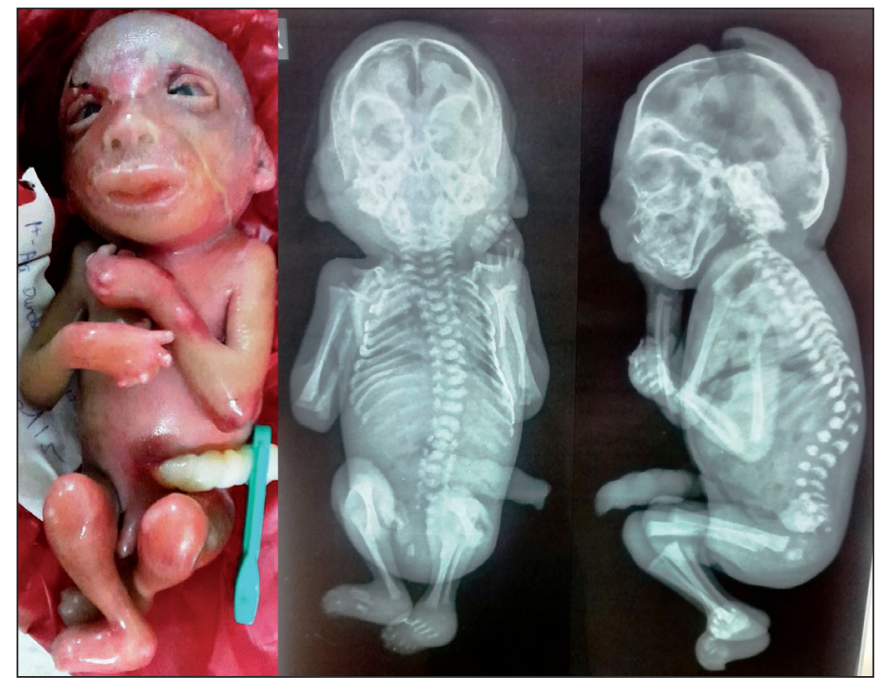

Figure 1: Gross and X-Ray of fetus.

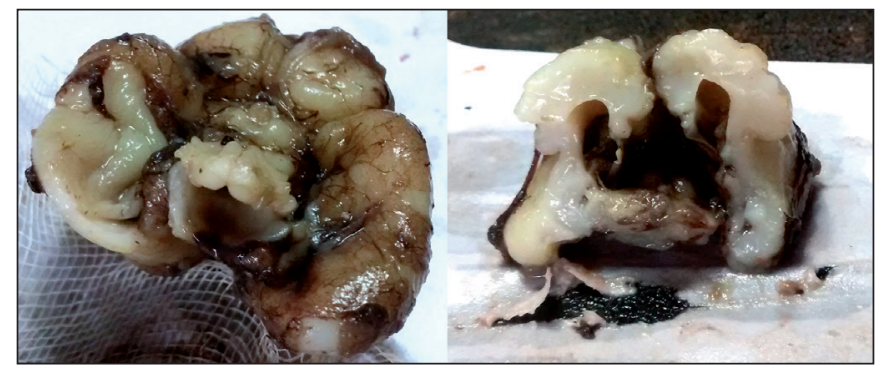

Figure 2: Brain showing hypoplastic brain stem and cerebellum with absence of corpus callosum and dilated lateral ventricle.

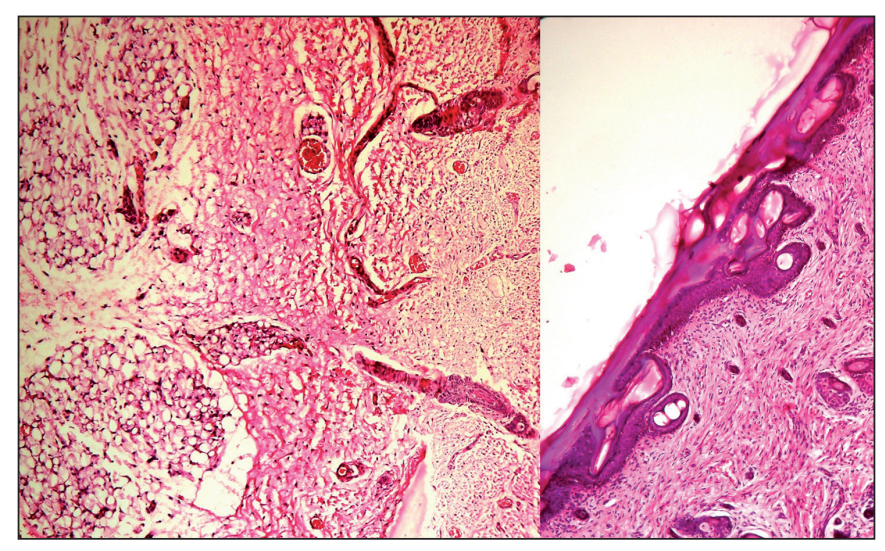

Figure 3: Microscopy of skin showing features of Ichthyosis (H\&E; x40).

the head and facial (craniofacial) region i.e. microcephaly (87\%), lissencephaly (40\%), absence of corpus callosum (53\%), and hypertelorism (94\%) result in a distinctive facial appearance and are the most common features (2).

NLS is characterised by abnormal accumulations of fluid in tissues throughout the body (generalized edema), permanent flexion and immobilization of multiple joints (flexion contractures), other limb malformations and/or abnormalities of the brain, skin, genitals, kidneys, and/ or heart (4). The typical and diagnostic facial appearance is peculiar to NLS. In the present case, the affected fetus had generalised edema, microcephaly, mild proptosis, hypertelorism, micrognathia, kyphosis, icthyosis, lissencephaly, hypoplastic cerebellum and brain stem with absence of corpus callosum. The weight of the brain in the present case was 15 grams. However, Lazjuk et al. reported a case where the brain weighed only $19.8 \mathrm{gm}$, which was the smallest recorded weight of the brain in a 39-week gestation (5). On histological examination, there is loss of neurons that is attributed to chromatolysis, cytoplasmic retraction, pyknosis, and chromatin fragmentation of motor neurons $(6,7)$. Kyphosis as seen in our case is a very rare finding and has been reported in a case report by Hemalatha et al. (1). Other CNS abnormalities reported include lissencephaly, microgyria, hypoplastic cerebellum, abnormalities of corpus callosum and lateral ventricles and aplasia of olfactory structures and the optic nerves. The hallmark of this syndrome is presence of excessive subcutaneous tissue deposition with edema (8).

Several hypotheses have been proposed for these symptoms. Karimi-Nejad et al. mentioned ichthyotic skin as the cause of many features (9). Tos et al. claimed that the characteristic features of NLS resemble "restrictive dermopathies" (10). This skin change leads to protein loss that causes hypoproteinemia and polyhydramnios, generalized edema and swollen limbs in utero. Limb deformities and flexion contractures are also the result of these dermatopathies. The tight skin of the fetus reduces fetal movement leading to failure of swallowing and development of contractures. Chromosome analysis is normal, but some genetic alterations have been noted. Some of the recent studies on animals showed that the genes associated with epidermal differentiation on human chromosomes $6 \mathrm{q}$ and $9 \mathrm{p}$ must be investigated thoroughly (10). Cerebro-oculo-facioskeletal (COFS) syndrome is a common differential of NLS with similar craniofacial malformations (microcephaly with brain hypoplasia), musculoskeletal defects (flexion contracture, micrognathia) and malformations of the brain and spinal cord. However, the typical deep set eyes with blepharophimosis and prominent root of the nose are in contrast to the protruding eyes and flattened nose seen in NLS. Several other differentials of NLS are summarised in Table I.

The exact underlying pathogenesis of NLS still remains unknown. But most authors believe that NLS may be a 
Table I: Differential diagnosis of NLS $(8,11)$

\begin{tabular}{ll}
\hline Differential Diagnosis & Characteristic features \\
\hline Cerebro-oculo-facio-skeletal (COFS) syndrome & $\begin{array}{l}\text { craniofacial malformations, ocular abnormalities, musculoskeletal } \\
\text { defects, malformations and progressive degenerative changes of the } \\
\text { brain and spinal cord }\end{array}$ \\
\hline Walker-Warburg syndrome & $\begin{array}{l}\text { severe congenital oculo-cerebral abnormalities, including lissencephaly } \\
\text { and ventriculomegaly }\end{array}$ \\
\hline Pena-Shokeir syndrome type I & $\begin{array}{l}\text { abnormal fetal movement profile, craniofacial malformations, } \\
\text { pulmonary hypoplasia, IUGR }\end{array}$ \\
\hline Multiple pterygium syndrome & $\begin{array}{l}\text { growth retardation, webbing of the skin, permanent flexion of certain } \\
\text { joints, skeletal abnormalities, and craniofacial malformations }\end{array}$ \\
\hline
\end{tabular}

complex neuro (oculo) ectodermal dysplasia-mesenchymal dyshistogenesis syndrome.

In conclusion, we report a rare case of NLS associated with kyphosis, which is an uncommon presentation. Early diagnosis of NLS with genetic counseling and serial ultrasound examination of at-risk families is essential and such pregnancies should be terminated. Emphasis should be provided on public awareness in the form of genetic counseling and risks associated with consanguinity to reduce the incidence of NLS.

\section{REFERENCES}

1. Hemalatha A, Shilpa K, Deepthi B, Neelima P. Perinatal autopsy of a rare lethal condition - Neu Laxova Syndrome. International Journal of Medical and Applied Sciences. 2013;2:186-92.

2. Jones K. Smith's recognizable patterns of human malformation. 5th ed. Philadelphia: W.B. Saunders Company; 1997. 174-83.

3. Acuna-Hidalgo R, Schanze D, Kariminejad A, Nordgren A, Kariminejad MH, Conner P, Grigelioniene G, Nilsson D, Nordenskjöld M, Wedell A, Freyer C, Wredenberg A, Wieczorek D, Gillessen-Kaesbach G, Kayserili H, Elcioglu N, Ghaderi-Sohi S, Goodarzi P, Setayesh H, van de Vorst M, Steehouwer M, Pfundt R, Krabichler B, Curry C, MacKenzie MG, Boycott KM, Gilissen C, Janecke AR, Hoischen A, Zenker M. Neu-Laxova syndrome is a heterogeneous metabolic disorder caused by defects in enzymes of the L-serine biosynthesis pathway. Am J Hum Genet. 2014;95:285-93.
4. Scott C, Louro J, Laurence K, Tolarová M, Hall J, Reed S. Comments on the Neu-Laxova syndrome and CAD complex. Am J Med Genet. 1981;9:165-75.

5. Lazjuk GI, Lurie IW, Ostrowskaja TI, Cherstvoy ED, Kirillova IA, Nedzved MK, Usoev SS. Brief clinical observations: The NeuLaxova syndrome-a distinct entity. Am J Med Genet. 1979;3:26167.

6. Squier W, Ferechte ER. Central nervous system. In: Cohen MC, Scheimberg I, editors. The pediatric and perinatal autopsy manual. Cambridge: Cambridge University Press; 2014. 173-204.

7. Ferechte ER. Brain malformations. In: Khong TY, Malcomson RDG, editors. Keeling's fetal and neonatal pathology. Switzerland: Springer; 2015. 709-728.

8. Aslan H, Gul A, Polat I, Mutaf C, Agar M, Ceylan Y. Prenatal diagnosis of Neu-Laxova syndrome: A case report. BMC Pregnancy Childbirth. 2002;2:1.

9. Karimi-Nejad M, Khajavi H, Gharavi M, Karimi-Nejad R. NeuLaxova syndrome: Report of a case and comments. Am J Med Genet. 1987;28:17-23.

10. Tos T, Diniz G, Ceylaner S, Aktaş S, Altınyurt S, Erbay G. NeuLaxova syndrome: A terrible phenotypic appearance caused by an undefined genetic alteration. APJ. 2006;3:5-9.

11. Tarim E, Bolat F. Prenatal diagnosis and postmortem findings of Neu-laxova syndrome. J Turk-Ger Gynecol Assoc. 2010;11:2257. 